\title{
Importance of a micro-diet for scleractinian corals
}

\author{
Fanny Houlbrèque*, Eric Tambutté, Cécile Richard, Christine Ferrier-Pagès
}

Centre Scientifique de Monaco, Avenue Saint-Martin, 98000 Monaco (Principality of Monaco)

\begin{abstract}
This study investigated the ability of 3 coral species - zooxanthellate (Stylophora pistillata and Galaxea fascicularis) and azooxanthellate (Tubastrea aurea) - to feed on pico- and nanoplankton (particles $<100 \mu \mathrm{m}$ ). Coral nubbins were incubated for $6 \mathrm{~h}$ in flow chambers containing the planktonic particles (experimental chambers). Control chambers were also set up to follow the natural changes in the planktonic community. Changes in the concentrations of dissolved organic carbon (DOC), bacteria, cyanobacteria and flagellates were monitored during the incubation. Results showed that ingestion rates were proportional to prey concentrations. In terms of number of prey ingested per polyp, bacteria were the first group ingested. When converted into carbon and nitrogen, nanoflagellates represented the most important contribution, amounting to $84-94 \%$ of the total carbon and $52-85 \%$ of the total nitrogen ingested. Bacteria, cyanobacteria and picoflagellates accounted only for $1-7 \%$ of the ingested carbon. At the end of the incubation, DOC concentrations increased in the chambers containing $T$. aurea and G. fascicularis. However, in all chambers containing $S$. pistillata, DOC concentrations decreased (from $101.69 \pm 13.53$ to $93.59 \pm 4.67 \mu \mathrm{mol} \mathrm{DOC}^{-1}$ ) equal to a rate of $0.251 \pm 0.217 \mathrm{nmol}$ DOC polyp $\mathrm{p}^{-1} \mathrm{~h}^{-1}$. In symbiotic species, pico- and nanoplankton accounted for only $6.6-7.8 \%$ of the carbon supplied by photosynthesis but were a major supply of nitrogen. In $S$. pistillata, the amount of nitrogen supplied by pico- and nanoplankton ingestion (1.2 ng $\mathrm{N}$ polyp $\mathrm{p}^{-1} \mathrm{~h}^{-1}$ ) was as high as the amount supplied by the dissolved nitrogen uptake (1.55 ng $\mathrm{N}$ polyp $\mathrm{p}^{-1} \mathrm{~h}^{-1}$ ). Pico- and nanoplankton may, therefore, constitute an important food source for these corals.
\end{abstract}

KEY WORDS: Scleractinian corals · Heterotrophy · Grazing rates · Picoplankton · Nanoplankton • $\mathrm{DOC} \cdot \mathrm{DON}$ Resale or republication not permitted without written consent of the publisher

\section{INTRODUCTION}

Scleractinian corals are sessile benthic organisms that can feed on a large range of food sources, from dissolved organic carbon (DOC) (Al-Moghrabi et al. 1993) and bacteria (Sorokin 1991) to macrozooplankton (Sebens et al. 1996). Heterotrophy is important for most corals (Sebens et al. 1996, Ferrier-Pagès et al. 2003, Houlbrèque et al. 2003); it is primarily a source of nitrogen, phosphorus and amino acids not supplied via symbiont photosynthesis (Muscatine \& Porter 1977), which mostly brings carbon-rich compounds to the animal (Sebens 1987, Lewis 1992, Cook et al. 1994, Risk et al. 1994). Heterotrophy can, therefore, be an important source of energy depending on the environmental conditions, since it may bring more than $60 \%$ of the total energy to corals living in deep waters or in shaded environments (Falkowski et al. 1984). A strong heterotrophic signature has been found in the isotopic composition of the tissue and skeleton of deep corals (Muscatine \& Kaplan 1994, Grottoli \& Wellington 1999, Grottoli 2000). Several studies have shown that an input of particulate food induces significant changes in most of the physiological parameters of scleractinian corals. Photosynthetic rates, as well as tissue and skeletal growth rates, are highly enhanced in fed compared to starved corals (Witting 1999, Anthony \& Fabricius 2000, Ferrier-Pagès et al. 2003, Houlbrèque et al. 2003).

Despite the potential importance of feeding, few quantitative data are available on natural prey ingestion rates, prey selection and prey availability (Johannes \& Tepley 1974, Porter 1974, Johnson \& 
Sebens 1993, Sebens et al. 1996, Witting 1999). Most of the above studies have concentrated on the ingestion of meso- and macrozooplankton over time scales of hours. They have shown that corals can be active predators, ingesting from 0.5 to 2 prey items per polyp (Sebens et al. 1996). Very few studies have investigated the ability of scleractinian corals to feed on picoand nanoplankton (fraction $<100 \mu \mathrm{m}$ including bacteria, cyanobacteria, flagellates and ciliates (Azam et al. 1983). Microbial communities play a key role in marine food webs (Pomeroy et al. 1974) since they are the main contributors to pelagic planktonic communities in terms of biomass (Stockner \& Antia 1986, Ducklow 1990) and production (Platt et al. 1983). In reef waters, concentrations may be as high as $10^{6}$ bacteria $\mathrm{ml}^{-1}$, $10^{4}$ to $10^{5}$ cyanobacteria $\mathrm{ml}^{-1}$ and up to $10^{4}$ total flagellates (Ducklow 1990, Sorokin 1991, Ferrier-Pagès \& Gattuso 1998). Due to their rapid growth rates, heterotrophic bacterioplankton account for a significant part of the carbon and nitrogen flow to upper trophic levels (Azam et al. 1983). As a consequence, much research has been conducted on the dynamics of these planktonic communities in reef waters.

Sorokin (1973) was one of the first to suggest that corals consume organic phosphorus in forms of planktonic bacteria rather than taking up inorganic phosphorus at the same concentrations. Herndl \& Velimirov (1985) found a large bacterial population within the coelenteron of 4 anthozoan species, suggesting that corals are able to farm and feed on bacteria. It has also been demonstrated that corals can actually feed on bacteria and protozoa in culture (Farrant et al. 1987, Sorokin 1991, Ferrier-Pagès et al. 1998) or on particulate matter in general (Anthony 1999). Bak et al. (1998) measured a significant consumption of bacteria by colonies of Madracis mirabilis. In parallel, some studies also showed that pico- and nanoplankton were actively removed from the water flowing above reef flats (Moriarty et al. 1985, Ayukai 1995) and that phytoplankton was largely used by soft corals for their nutritional needs (Fabricius et al. 1995, 1998). More recently, Ribes et al. (2003) calculated high rates of pico- and nanoplankton uptake by coral reef communities (including corals, sponges, tunicates, cnidarians and bryozoans) incubated in a flume tank. DOC has also to be taken into account as a potential food source for corals; it constitutes the vast majority of the organic carbon pool in the oceans (Sharp 1997) and was shown to be a significant food source for several aquatic metazoans (Reiswig 1971, Smith \& Kaufmann 1999, Yahel et al. 2003) including corals (Al-Moghrabi et al. 1996).

No experimental or in situ studies have investigated the uptake of pico- and nanoplankton by individual scleractinian corals. However, such studies have been performed on hydrozoans (Coma et al.
1999), octocorals (Ribes et al. 1998) and gorgonians (Ribes et al. 1998, 1999). Description and quantification of the diet are, however, essential for assessing the amount of energy transferred from the plankton to the benthos.

\section{MATERIALS AND METHODS}

Biological material. This study was conducted on 3 different species: 2 zooxanthellate scleractinian corals, Stylophora pistillata (Esper, 1797) and Galaxea fascicularis (Linnaeus, 1767) collected in the Gulf of Aqaba (Red Sea); and an azooxanthellate coral, Tubastrea aurea collected in South East Asia. S. pistillata has small polyps and is widely distributed in the whole Indo-Pacific area (Veron 2000). Gattuso (1987) showed in the Gulf of Aqaba that this species inhabits a wide bathymetric range from the surface to $100 \mathrm{~m}$ depth. G. fascicularis, with much larger polyps, is also widely distributed throughout the Indo-Pacific as a common and dominant component of inshore fringing reefs (Veron \& Pichon 1976, Veron 2000). Tubastrea species are found on most of the world's coral reefs and are commonly seen on exposed rocks alongside zooxanthellate corals (Veron 2000). They are characterized by big corallites with porous walls. The 3 species were maintained at least 3 mo in the laboratory under controlled conditions. For the feeding experiments, colonies were prepared (either by cutting the apical end branches for $S$. pistillata, or individual polyps for the other 2 species) to produce nubbins. Coral nubbins were glued on Plexiglas ${ }^{\circledR}$ slides with underwater Epoxy $^{\circledR}$ glue and were allowed to grow for 3 to $4 \mathrm{wk}$ until they reached a height of ca. $3 \mathrm{~cm}$ for $S$. pistillata and $2 \mathrm{~cm}$ diameter for the other 2 species. The whole skeleton of these nubbins was covered with tissue. Ten slides were prepared for each species.

Feeding experiments. Uptake of DOC and predation on pico- and nanoplankton were assessed using Plexiglas ${ }^{\circledR}$ flow tanks according to Levy et al. (2001), based on the procedures described by Vogel \& LaBarbera (1978). Each tank was $40 \mathrm{~cm}$ long $\times 4 \mathrm{~cm}$ wide $\times 10 \mathrm{~cm}$ high and was incubated in a water bath maintaining a constant temperature of $26^{\circ} \mathrm{C}$. In the tanks, water was re-circulated by a motor-driven propeller with a defined rotational speed. Flow velocity was measured by following the movement of brightly illuminated plastic beads added to the water. The bead movements were recorded with a video camera and the flow velocity was calculated as described by Trager et al. (1990). It has been shown that particle capture in corals is dependent on the water flow. The flow giving maximal particle capture is itself dependent on the coral species and the type of food (Kim \& Lasker 1997, Sebens et al. 
1997). Flow test experiments were, therefore, performed and showed that maximal ingestion rates for Galaxea fascicularis, Stylophora pistillata and Tubastrea aurea were found at flow rates of 2.7, 3.6 and $7 \mathrm{~cm} \mathrm{~s}^{-1}$, respectively (data not shown). These flows were not very different from each other since they are at the lower range of flows that might be experienced by corals in situ (Atkinson \& Bilger 1992, Helmuth \& Sebens 1993, Fabricius et al. 1995, Anthony 1997). Subsequent experiments were all performed under these flow conditions in summer (July-August), when the surface seawater temperature was ca. $25^{\circ} \mathrm{C}$ to avoid any temperature stress for the micro-organisms.

For each experiment, 4 tanks were filled with $1.5 \mathrm{l}$ of Mediterranean seawater prepared as described below. Seawater was taken every morning in front of the laboratory (collection site: $2 \mathrm{~m}$ depth, NW Mediterranean Sea, at $200 \mathrm{~m}$ from the coast), filtered through a $100 \mu \mathrm{m}$ mesh size filter to exclude large zooplankton, and then concentrated 4 times on a $1 \mu \mathrm{m}$ filter using a reverse filtration apparatus to avoid cell breakage and lysis (Sheldon \& Rassoulzadegan 1987). Three coral nubbins, from the same species, were incubated in each of 3 tanks, while 1 tank was kept as a control (without corals). For each coral species, a total of 10 incubations were carried out over $6 \mathrm{~h}$ in the dark. Control tanks (without corals) were very important in this kind of experiment since they allowed us to estimate the decrease in pico- and nanoplankton concentrations due to internal grazing (within the microbial loop), or natural death. This decrease is independent of coral predation and has to be taken into account in the following equations for grazing rate.

Samples were taken in each chamber at the beginning and at the end of the $6 \mathrm{~h}$ incubation (after having thoroughly mixed the seawater). Three samples (triplicates of $10 \mathrm{ml}$ ) were fixed with paraformaldehyde (0.4\% final concentration), stained with DAPI (Porter \& Feig 1980), filtered on $0.22 \mu \mathrm{m}$ black Nuclepore filters and frozen at $-20^{\circ} \mathrm{C}$ until further analysis. The filters were used for the visual quantification of pico- and nanoplankton (heterotrophic bacteria, cyanobacteria, auto- and heterotrophic flagellates) on an epifluorescence microscope (Ferrier-Pagès \& Gattuso 1998). Bacteria and heterotrophic flagellates were stained with DAPI and counted under UV excitation. Autotrophic cells were counted under blue light excitation. Carbon and nitrogen content of prey items were estimated using literature conversion factors (summarized in Tables $1 \& 2$ ). These factors are those used in the other studies on anthozoan feeding. The cell size was measured under a microscope and cell biovolumes were estimated assuming the nearest geometrical shape (Edler 1979). Biovolumes were equal to 0.048, 0.2, 1.77 and $65.45 \mu^{3}$ for heterotrophic bacteria, cyanobacte-
Table 1. Carbon and nitrogen contents of the different prey items calculated using literature conversion factors

\begin{tabular}{|c|c|c|c|}
\hline Group & $\begin{array}{l}\text { Carbon } \\
\text { content } \\
\left.\text { fg } C \mu m^{-3}\right)\end{array}$ & $\begin{array}{c}\text { Nitrogen } \\
\text { content } \\
\left(\mathrm{fg} N \mu \mathrm{m}^{-3} \text { ) }\right.\end{array}$ & Source \\
\hline Bacteria & 148 & 3.8 & $\begin{array}{l}\text { Gundersen et al. } \\
\text { (2001) } \\
\text { Caron et al. (1995) }\end{array}$ \\
\hline Cyanobacteria & 700 & 50 & $\begin{array}{l}\text { Jochem (1988) } \\
\text { Caron et al. (1995) }\end{array}$ \\
\hline Picoflagellates & 220 & 26 & $\begin{array}{l}\text { Bratbak (1987) } \\
\text { Caron et al. (1995) }\end{array}$ \\
\hline Nanoflagellates & 220 & 26 & $\begin{array}{l}\text { Bratbak (1987) } \\
\text { Caron et al. (1995) }\end{array}$ \\
\hline
\end{tabular}

Table 2. Characteristics of the coral colonies used in this experiment (mean $\pm \mathrm{SD}, \mathrm{n}=10$ for each species)

\begin{tabular}{|lccc|}
\hline Species & $\begin{array}{c}\text { Polyp } \\
\text { number } \\
\text { (mean } \pm \text { SD) }\end{array}$ & $\begin{array}{c}\text { Diameter } \\
\text { of polyp } \\
(\mathrm{mm})\end{array}$ & $\begin{array}{c}\text { Protein } \\
(\mathrm{mg})\end{array}$ \\
\hline Stylophora pistillata & $849 \pm 89$ & $0.5-1$ & $19 \pm 5$ \\
Galaxea fascicularis & $38 \pm 9$ & $5-7$ & $19 \pm 3$ \\
Tubastrea aurea & $15 \pm 4$ & $10-12$ & $196 \pm 69$ \\
\hline
\end{tabular}

ria, and pico- and nanoflagellates, respectively. Three $50 \mathrm{ml}$ water samples were preserved with Lugol's acid (10\% final concentration) and settled in Utermöhl chambers for the quantification of ciliates on an inverted microscope. DOC was measured by filtering $10 \mathrm{ml}$ water samples through pre-combusted GF/F glass fiber filters. The filtered water was stored in prescored vials (Wheaton) at $-20^{\circ} \mathrm{C}$ until analysis by high-temperature catalytic oxydation on an autoanalyzer (Shimadzu TOC-5000).

Grazing rates were calculated according to the equations of Ribes et al. (1998), derived from the equations of Frost (1972), which take into account the growth of the prey during the incubations. The growth rate of the prey $\left(k, h^{-1}\right)$ was calculated as:

$$
k=\ln \left(C_{t} / C_{0}\right) / T_{t}-T_{0}
$$

where $C_{0}$ and $C_{t}$ are the prey concentrations in the chambers (cell $\mathrm{ml}^{-1}$ ) at the initial time $T_{0}$ and at the final time $T_{t}$, respectively. $g$ is the grazing coefficient $\left(\mathrm{h}^{-1}\right)$ calculated as:

$$
g=k_{\mathrm{C}}-k_{\mathrm{g}}
$$

where $k_{\mathrm{c}}$ is the prey growth rate in the control chamber $\left(\mathrm{h}^{-1}\right)$ and $k_{\mathrm{g}}$ is the growth in the coral chambers $\left(\mathrm{h}^{-1}\right)$. The ingestion rate $I$ (prey ingested ind.$^{-1} \mathrm{~h}^{-1}$ ) is:

$$
I=F C
$$


where $F\left(\right.$ cell $\left.^{-1}\right)$ is the filtration rate calculated as follows:

$$
F=V \times g / N
$$

where $V$ is volume of seawater in the chamber $(\mathrm{ml}), g$ the grazing coefficient $\left(\mathrm{h}^{-1}\right)$ and $N$ the total concentration of prey in the chamber (cells ml ${ }^{-1}$ ). $C$ is the average prey concentration (cells ml ${ }^{-1}$ ) during the experiment calculated as follows:

$$
C=C_{0}\left[\mathrm{e}^{(k-g)\left(T_{t}-T_{0}\right)}-1\right] /(k-g)\left(T_{t}-T_{0}\right)
$$

We chose to express ingestion rates either per protein content or per polyp, which are the 2 parameters involved in food capture (since protein is a measure of the total tissue biomass and polyps are the predation unit). Presently, polyp is the most common sizenormalizing parameter in coral feeding studies (Clayton \& Lasker 1982, Lasker et al. 1983, Sebens et al. 1996, Ribes et al. 1998, 1999, Piniak 2002) and protein normalization allows comparison between species. Skeletal surface area was not a good normalization unit in this experiment because of the shape and the size of polyps of Tubastrea aurea and Galaxea fascicularis species (Table 2). These 2 species indeed have large polyps deeply penetrated by coral tissue to a depth of several millimeters. Edmunds \& Gates (2002) already observed that none of the available methods for calculating surface skeletal area quantify the actual area of coral tissue, which arguably is more biologically relevant than skeletal area in normalizing the flux of important solutes or particles. These authors, therefore, concluded that normalizing to biomass (protein) is the most effective method to account for coral size in comparative studies.

The total number of polyps for each colony was counted, using a dissecting scope for the species Stylophora pistillata. The protein content of the colony tissue was measured, after tissue extraction with a Water Pick, using the BC Assay Kit (Interchim). This measurement is based on the colorimetric determination of the amount of protein (Smith et al. 1985). The standard curve was established with bovine serum albumin standards.

\section{RESULTS}

The characteristics of the 3 coral species studied are summarized in Table 2 . The range of prey concentrations at the beginning of the experiments was: bacteria $\left(850 \pm 33 \times 10^{3}\right.$ cells $\left.\mathrm{ml}^{-1}\right)$, cyanobacteria $(52.7 \pm 7.4 \times$ $10^{3}$ cells ml$^{-1}$ ), heterotrophic pico- and nanoflagellates $\left(9.6 \pm 4.9 \times 10^{3}\right.$ and $4.8 \pm 2.8 \times 10^{3}$ cells ml ${ }^{-1}$, respectively), autotrophic pico- and nanoflagellates $(1.7 \pm 0.9$ $\times 10^{3}$ and $1.9 \pm 0.9 \times 10^{3} \mathrm{cells} \mathrm{ml}^{-1}$, respectively). Ciliate concentrations were too low $\left(0.126 \pm 0.15\right.$ cells ml $\left.^{-1}\right)$ to detect any significant consumption by the corals and are, therefore, not taken further into account. Fig. 1 shows the mean growth rates obtained for each picoand nanoplankton group in the control and experimental tanks after $6 \mathrm{~h}$ incubation. These growth rates are mean values of 15 incubations performed for each coral species. They are either positive, when cell concentrations increased during the incubation, or negative, when cell concentrations decreased. We observe that in the control tanks, there is no important positive

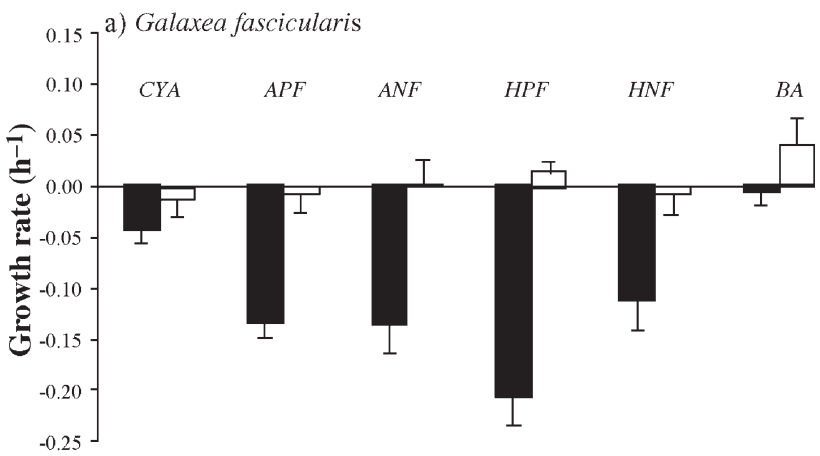

b) Tubastrea aurea

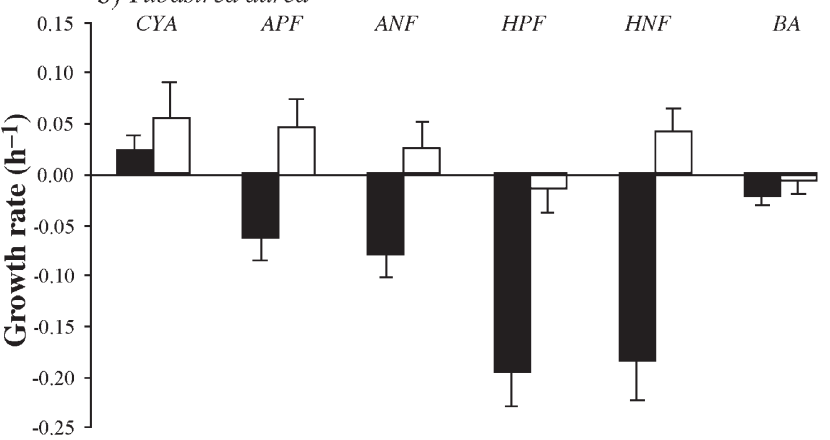

c) Stylophora pistillata

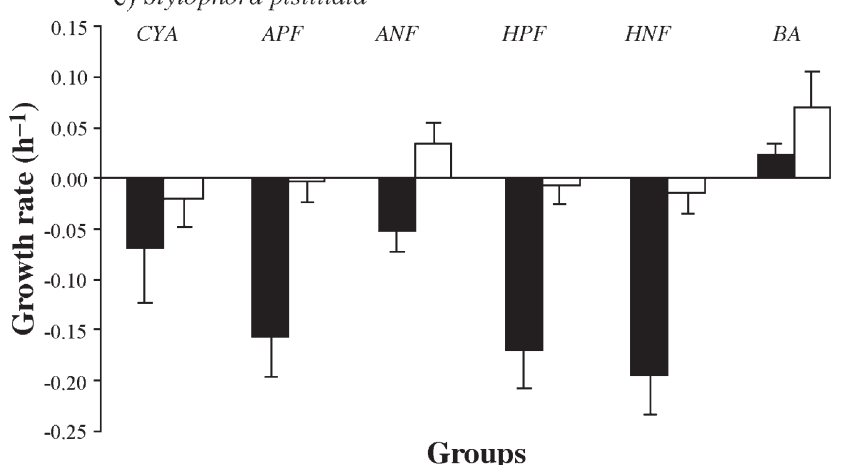

Groups

Fig. 1. Mean growth rates $\left(\mathrm{h}^{-1}\right)$ calculated from Eq. (1) and obtained in the control and experimental tanks for the different groups of organisms. Data represent mean and standard deviation of 15 incubations (for each species). White and black bars represent growth rates measured in the control and experimental tanks, respectively. CYA: cyanobacteria; APF: autotrophic picoflagellates; ANF: autotrophic nanoflagellates; HPF: heterotrophic picoflagellates; HNF: heterotrophic nanoflagellates; BA: bacteria 
or negative growth, meaning that cell concentrations remained stable in the absence of coral grazing. However, in the experimental tanks containing coral nubbins, cell concentrations largely decreased during the incubation. This population change was taken into account in the equations used to calculate the number of prey ingested.

In terms of number of prey ingested, normalized either to the protein content (Table 3) or the number of polyps (Fig. 2), bacteria were quantitatively the major group, followed by cyanobacteria and heterotrophic flagellates (ANOVA, $\mathrm{p}<0.05$ ). The proportion of each type of prey ingested was comparable for all coral species $(90.4 \pm 2.2 \%$ of bacteria, $5.3 \pm 2.0 \%$ of cyanobacteria, $2.4 \pm 1.3 \%$ of total heterotrophic flagellates, and $1.9 \pm 0.5 \%$ of total autotrophic flagellates).

When converted into amounts of carbon and nitrogen ingested, per polyp or per protein, nanoflagellates (both auto- and heterotrophic) represented the most important contribution, i.e. 84 to $94 \%$ of the total C input and 51.9 to $85.18 \%$ of the total N (Table 3, Fig. 3). Bacteria, cyanobacteria and picoflagellates contributed only 1 to $7 \%$ of the total ingested amounts of carbon and nitrogen. When results are expressed per protein, we observed higher ingestion rates for the 2 symbiotic species compared to the asymbiotic one

Table 3. Ingestion rates expressed either in number of prey, or in carbon (C) or nitrogen $(\mathrm{N})$ equivalent and normalized per protein for the 3 coral species $($ mean $\pm \mathrm{SD})(\mathrm{n}=15)$. BA: bacteria; CYA: cyanobacteria; APF: autotrophic picoflagellates; ANF: autotrophic nanoflagellates; HPF: heterotrophic picoflagellates; HNF: heterotrophic nanoflagellates

\begin{tabular}{|lccc|}
\hline Group & Galaxea fascicularis & Stylophora pistillata & Tubastrea aurea \\
\hline Number of prey $\mathrm{mg}^{-1}$ protein $^{-1}$ & & \\
$\mathrm{BA}$ & $1.65 \pm 0.37 \times 10^{6}$ & $1.50 \pm 0.35 \times 10^{6}$ & $0.07 \pm 0.03 \times 10^{6}$ \\
$\mathrm{CYA}$ & $80.23 \pm 20.19 \times 10^{3}$ & $241.47 \pm 100.59 \times 10^{3}$ & $3.01 \pm 1.38 \times 10^{3}$ \\
$\mathrm{APF}$ & $3.65 \pm 0.66 \times 10^{3}$ & $13.24 \pm 5.95 \times 10^{3}$ & $0.49 \pm 0.10 \times 10^{3}$ \\
$\mathrm{ANF}$ & $5.56 \pm 0.84 \times 10^{3}$ & $5.23 \pm 1.02 \times 10^{3}$ & $0.76 \pm 0.16 \times 10^{3}$ \\
$\mathrm{HPF}$ & $39.15 \pm 6.04 \times 10^{3}$ & $29.11 \pm 3.25 \times 10^{3}$ & $3.94 \pm 0.76 \times 10^{3}$ \\
$\mathrm{HNF}$ & $19.75 \pm 7.54 \times 10^{3}$ & $12.56 \pm 3.25 \times 10^{3}$ & $2.11 \pm 0.46 \times 10^{3}$ \\
& & & \\
$\mathrm{ng} \mathrm{C} \mathrm{mg}^{-1}$ protein $\mathrm{h}^{-1}$ & & \\
$\mathrm{BA}$ & $11.75 \pm 2.60$ & $10.67 \pm 2.47$ & $0.51 \pm 0.19$ \\
$\mathrm{CYA}$ & $11.23 \pm 2.83$ & $33.81 \pm 14.08$ & $0.42 \pm 0.19$ \\
$\mathrm{APF}$ & $1.42 \pm 0.26$ & $5.16 \pm 2.32$ & $0.19 \pm 0.04$ \\
$\mathrm{ANF}$ & $80.07 \pm 12.03$ & $75.24 \pm 14.74$ & $10.99 \pm 2.36$ \\
$\mathrm{HPF}$ & $15.25 \pm 2.35$ & $11.33 \pm 1.26$ & $1.54 \pm 0.30$ \\
$\mathrm{HNF}$ & $284.39 \pm 108.53$ & $180.81 \pm 46.74$ & $30.35 \pm 6.69$ \\
$\mathrm{ng} \mathrm{N} \mathrm{mg}$ & protein $\mathrm{h}^{-1}$ & & \\
$\mathrm{BA}$ & $5.93 \pm 2.63$ & $5.58 \pm 1.78$ & $0.28 \pm 0.25$ \\
$\mathrm{CYA}$ & $3.69 \pm 1.16$ & $12.05 \pm 1.17$ & $0.15 \pm 0.07$ \\
$\mathrm{APF}$ & $0.86 \pm 0.15$ & $3.18 \pm 2.34$ & $0.12 \pm 0.04$ \\
$\mathrm{ANF}$ & $18.33 \pm 1.14$ & $17.07 \pm 4.50$ & $2.54 \pm 4.50$ \\
$\mathrm{HPF}$ & $10.02 \pm 1.35$ & $6.69 \pm 4.66$ & $0.93 \pm 0.27$ \\
$\mathrm{HNF}$ & $65.06 \pm 12.98$ & $43.04 \pm 22.59$ & $6.89 \pm 2.89$ \\
& & & \\
\hline
\end{tabular}

(Table 4). Ingestion rates were proportional to the prey concentration in seawater (Fig. 4), with correlation coefficients close to 1 for the 3 coral species.

As far as DOC is concerned, concentrations increased in the incubation chambers containing Tubastrea aurea and Galaxea fascicularis (Table 5) compared to the change in DOC concentrations measured in the control chambers. These 2 species released DOC with rates, normalized per protein, 10 times higher for G. fascicularis compared to $T$. aurea. In all chambers containing Stylophora pistillata colonies, DOC concentrations decreased (compared to DOC changes in the control chambers). Contrary to the 2 other species, $S$. pistillata took up DOC at a rate of $1.02 \times 10^{-2} \mu \mathrm{mol}$ $\mathrm{mg}^{-1}$ protein $\mathrm{h}^{-1}$ (Table 5).

\section{DISCUSSION}

Pico- and nanoplankton dominate planktonic biomass and production in many oceanic regions (Tremblay \& Legendre 1994), where they contribute largely to the flow of carbon and nitrogen through the trophic chain. Up to now, coral feeding studies have mostly been limited to studying the capture of large organisms, which are easily recognizable in the gut content of the polyps (Porter 1974, Lasker 1981, Sebens \& Johnson 1991, 1996, Witting et al. 2002). However, gut content examination does not allow estimations of the grazing rates of small and soft-bodied prey such as pico- and nanoplankton because they are rapidly digested. Few studies have, therefore, been conducted on the ability of scleractinian corals to feed on the planktonic fraction $<100 \mu \mathrm{m}$ (DiSalvo 1971, Sorokin 1973, 1991, Farrant et al. 1987, Ferrier-Pagès et al. 1998). All the above studies showed that corals are able to feed on this type of prey. Sorokin (1973) was the first to use labelled bacteria to show that corals feed on bacterioplankton. Later, Ferrier-Pagès et al. (1998) incubated corals with ${ }^{3} \mathrm{H}$-labelled bacteria and ciliates. After a few hours, the amount of radioactivity measured in the coral tissue was proportional to the amount disappearing from the medium.

Our results indicate that 3 different coral species, symbiotic and asymbiotic, with small or large polyps, show a significant uptake of micro-organisms. Indeed, in the control tanks containing no coral colonies, no large decrease in prey concentrations (or in prey growth rate) could be observed. 

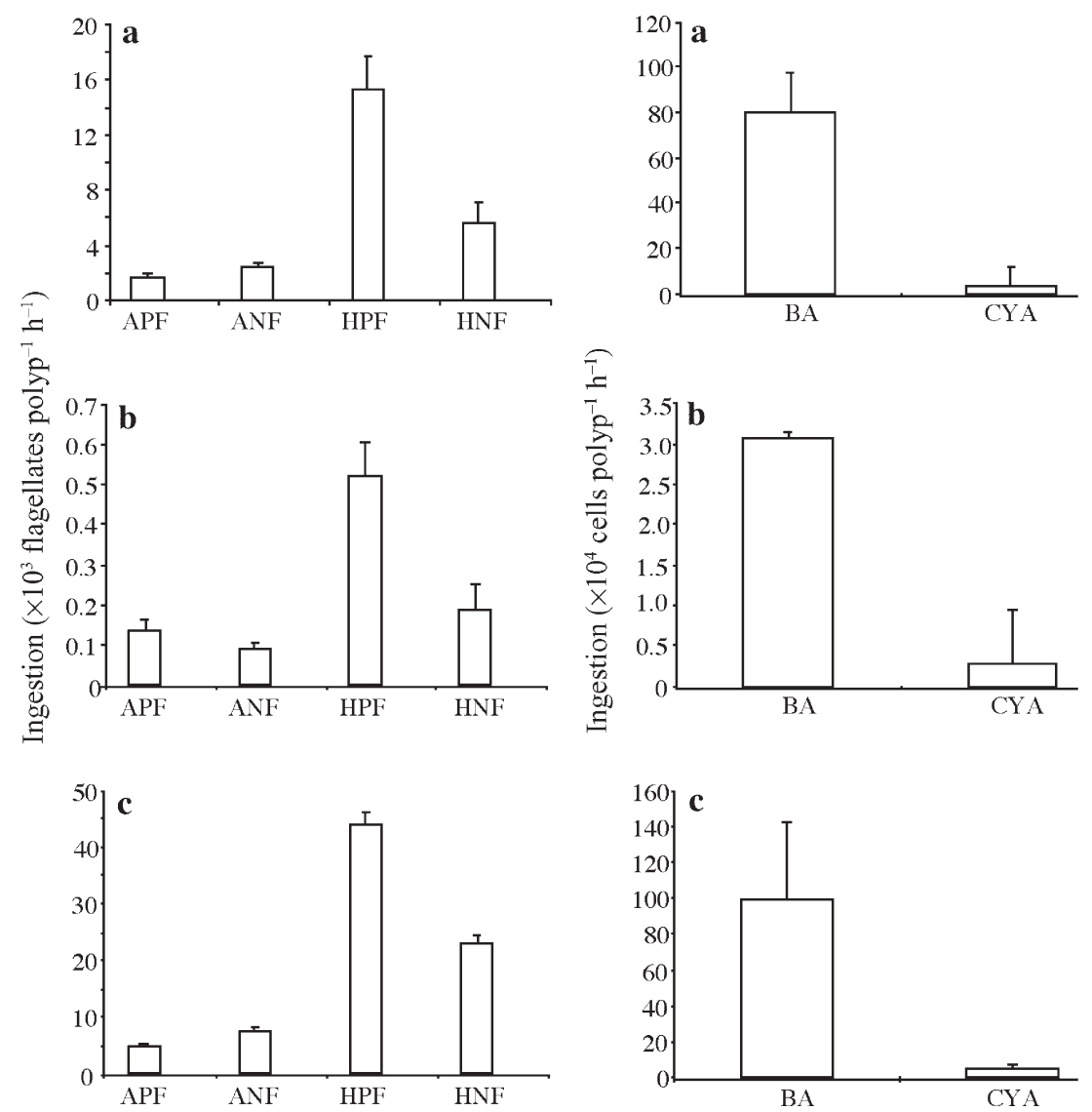

Fig. 2. Ingestion rates for the 3 coral species according to the type of prey. (a) Galaxea fascicularis, (b) Stylophora pistillata and (c) Tubastrea aurea (mean \pm $\mathrm{SD}, \mathrm{n}=15$ for each species). APF: autotrophic picoflagellates; ANF: autotrophic nanoflagellates; HPF: heterotrophic picoflagellates; HNF: heterotrophic nanoflagellates; BA: bacteria; CYA: cyanobacteria

Comparable results were also observed by Ribes et al. (1998) in their experimental and control chambers. This is the first time that coral feeding on a mixture of micro-organisms has been investigated, since in previous papers (Di Salvo 1971, Sorokin 1973, 1991, Farrant et al. 1987, Ferrier-Pagès et al. 1998), only 1 type of prey was used. In the present experiments, planktonic cells were concentrated 4 times to monitor as quickly as possible a significant change in cell concentration due to coral grazing, without enclosing corals for too long in the flume chambers. The use of short incubations also reduced the changes that might occur in the planktonic community (death due to enclosure or grazing of picoplankton by nanoplankton). Despite being concentrated, cells in our incubation chambers remain within the range of concentration observed in reef waters (Ribes et al. 2003). As already noticed in several studies on feeding (Anthony 1999, Ribes et al. 2003), anthozoan ingestion rates were a linear function of particle concentration. This suggests that either the particles stick to the coral mucus or that there is an active filtering taking place in the coral colonies. Six different feeding mechanisms have been described for corals (LaBarbera 1984) and one of the major mechanisms involved in uptake of small particles is the production of mucus nets (Muscatine 1973, Ferrier-Pagès et al. 1998). Release of mucus also serves to trap bacteria, which can use the dissolved and particulate matter contained in the mucus for their own growth, and in turn be grazed by protozoa that regenerate nutrients and represent potential food source for corals (Wild et al. 2004).

Nanoflagellates (both auto- and heterotrophic) seem to be a major food source for the 3 corals studied, in terms of carbon and nitrogen content. In this experiment, they represent 84 to $94 \%$ of the total ingested carbon and 52 to $85 \%$ of the total ingested nitrogen and, therefore, appear to be a most important group in the 'micro-diet' of the corals. This strongly suggests that only nanoplankton-sized cells might be of significant importance for coral nutritional needs. This was already observed for other anthozoans such as gorgonians (Coma \& Ribes 2003, Ribes et al. 2003). It was shown that Leptogorgia sarmentosa and Paramuricea clavata did not significantly capture prey smaller than nanoeukaryotes and that detrital particulate organic carbon constituted the bulk of the animals' diet (Ribes et al. 2003). The slight amount of carbon $(7 \%)$ derived from picoplanktonic cells (bacteria and cyanobacteria) might still provide essential amino-acids and vitamins (Bythell 1988). We found that the amount of carbon and nitrogen taken up by the 2 symbiotic species per unit protein is the same, independent of polyp size. The symbiotic species do, however, seem to ingest more carbon and nitrogen per protein than the asymbiotic species, which maybe relies more on large prey for its nutritional needs (and is more adapted to the capture of these large prey, due to its large polyps and long tentacles).

In the species Stylophora pistillata, maintained under our laboratory conditions ( $350 \mu \mathrm{mol}$ photons $\mathrm{m}^{-2}$ $\mathrm{s}^{-1}$ ), the amount of carbon provided by photosynthesis was estimated to be equal to $4773 \mathrm{ng} \mathrm{C} \mathrm{mg}^{-1}$ protein $\mathrm{h}^{-1}$ (Houlbrèque et al. 2003). The total ingestion of pico- and nanoplankton (317 $\mathrm{ng} \mathrm{C} \mathrm{mg}^{-1}$ protein $\mathrm{h}^{-1}$ ), therefore, represents $6.6 \%$ of the total amount of car- 

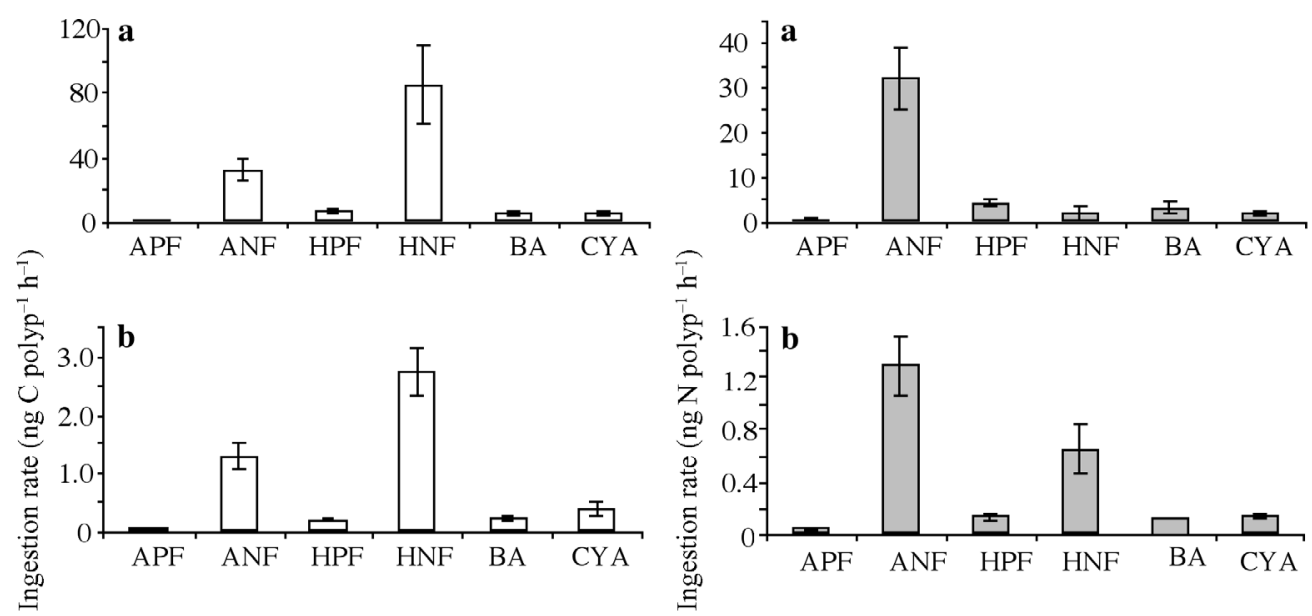

Fig. 3. Ingestion rates according to the type of prey. (a) Galaxea fascicularis, (b) Stylophora pistillata and (c) Tubastrea au-
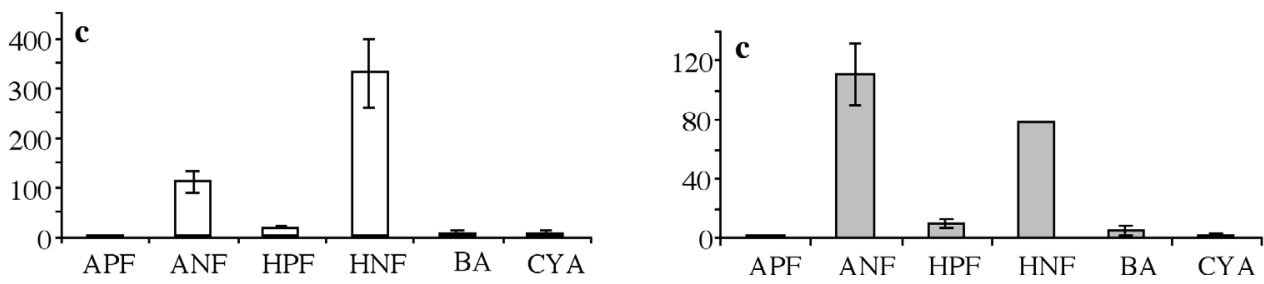
rea (mean $\pm \mathrm{SD})$. APF: autotrophic picoflagellates; ANF: autotrophic nanoflagellates; HPF: heterotrophic picoflagellates; HNF: heterotrophic nanoflagellates; BA: bacteria; CYA: cyanobacteria

Table 4. Total ingestion rates, expressed either in number of prey or carbon (C) and nitrogen (N), equivalent for the 3 coral species (mean $\pm \mathrm{SD})(\mathrm{n}=15)$

\begin{tabular}{|c|c|c|c|}
\hline Ingestion rate & Tubastrea aurea & Galaxea fascicularis & Stylophora pistillata \\
\hline No. of cells polyp ${ }^{-1} \mathrm{~h}^{-1}$ & $1720 \pm 722 \times 10^{3}$ & $1370 \pm 330 \times 10^{3}$ & $5.58 \pm 1.23 \times 10^{3}$ \\
\hline ng C polyp ${ }^{-1} \mathrm{~h}^{-1}$ & $472 \pm 78$ & $135 \pm 26$ & $4.9 \pm 0.5$ \\
\hline ng $N$ polyp ${ }^{-1} h^{-1}$ & $124 \pm 12$ & $19 \pm 3$ & $1.2 \pm 0.1$ \\
\hline No. of cells $\mathrm{mg}^{-1}$ protein $\mathrm{h}^{-1}$ & $370 \pm 61 \times 10^{3}$ & $0.30 \pm 0.06 \times 10^{3}$ & $13.60 \pm 4.57 \times 10^{3}$ \\
\hline $\mathrm{ng} \mathrm{C} \mathrm{mg}{ }^{-1}$ protein $\mathrm{h}^{-1}$ & $44 \pm 7$ & $404 \pm 78$ & $317 \pm 35$ \\
\hline $\mathrm{ng} \mathrm{N} \mathrm{mg}{ }^{-1}$ protein $\mathrm{h}^{-1}$ & $6 \pm 1$ & $56 \pm 8$ & $50 \pm 4$ \\
\hline
\end{tabular}

bon provided by photosynthesis. It is approximately the same for Galaxea fascicularis since the ingestion of pico- and nanoplankton also represented $7.8 \%$ of this total carbon provided by photosynthesis (photosynthesis: ca. $5178 \mathrm{ng} \mathrm{C} \mathrm{mg}^{-1}$ protein $\mathrm{h}^{-1}$, author's unpubl. data). The amount of nitrogen due to nanoplankton compared to the other sources of nitrogen can also be estimated. S. pistillata, for example, is able to take up ammonium and nitrate (at in situ concentrations) at a rate of ca. $2 \mathrm{ng} \mathrm{N} \mathrm{cm}{ }^{-2} \mathrm{~h}^{-1}$ (Grover et al. 2002, 2003) corresponding to $0.05 \mathrm{ng} \mathrm{N}$ polyp ${ }^{-1} \mathrm{~h}^{-1}$. In addition to inorganic nitrogen, corals can also take up some labile dissolved organic nitrogen, such as dissolved free amino acids (DFAA). Only limited data exist on DFAA uptake by corals (Ferrier 1991, Hoegh-Guldberg \& Williamson 1999). Hoegh-Guldberg \& Williamson (1999) estimated that the uptake of nitrogen in the form of DFAA was ca. $60 \mathrm{ng} \mathrm{N} \mathrm{cm}{ }^{-2} \mathrm{~h}^{-1}$ (or $1.5 \mathrm{ng} \mathrm{N}$ polyp $\mathrm{p}^{-1} \mathrm{~h}^{-1}$ ). This is a maximum value since it was after a $5 \mu \mathrm{M}$ enrichment in ${ }^{15} \mathrm{~N}$-DFAA. Therefore, the maximal amount of total inorganic nitrogen taken up is ca. $1.55 \mathrm{ng} \mathrm{N}$ polyp $^{-1} \mathrm{~h}^{-1}$. Our estimations show that small planktonic cells bring as much nitrogen as the dissolved source. This planktonic contribution can be underestimated if the amount of nitrogen in the picoand nanoplankton is higher, as has recently been suggested (Gundersen et al. 2002, Heldal et al. 2003), but only for 1 or 2 groups of organisms. This additional carbon and nitrogen derived from food might be important for enhancing coral growth rate (Houlbrèque et al. 2003).

Concerning the dissolved fraction, the interpretation of the DOC results remains complex. A significant release of DOC was observed in 2 out of 3 species, namely Galaxea fascicularis and Tubastrea aurea, compared to the change in DOC concentrations 

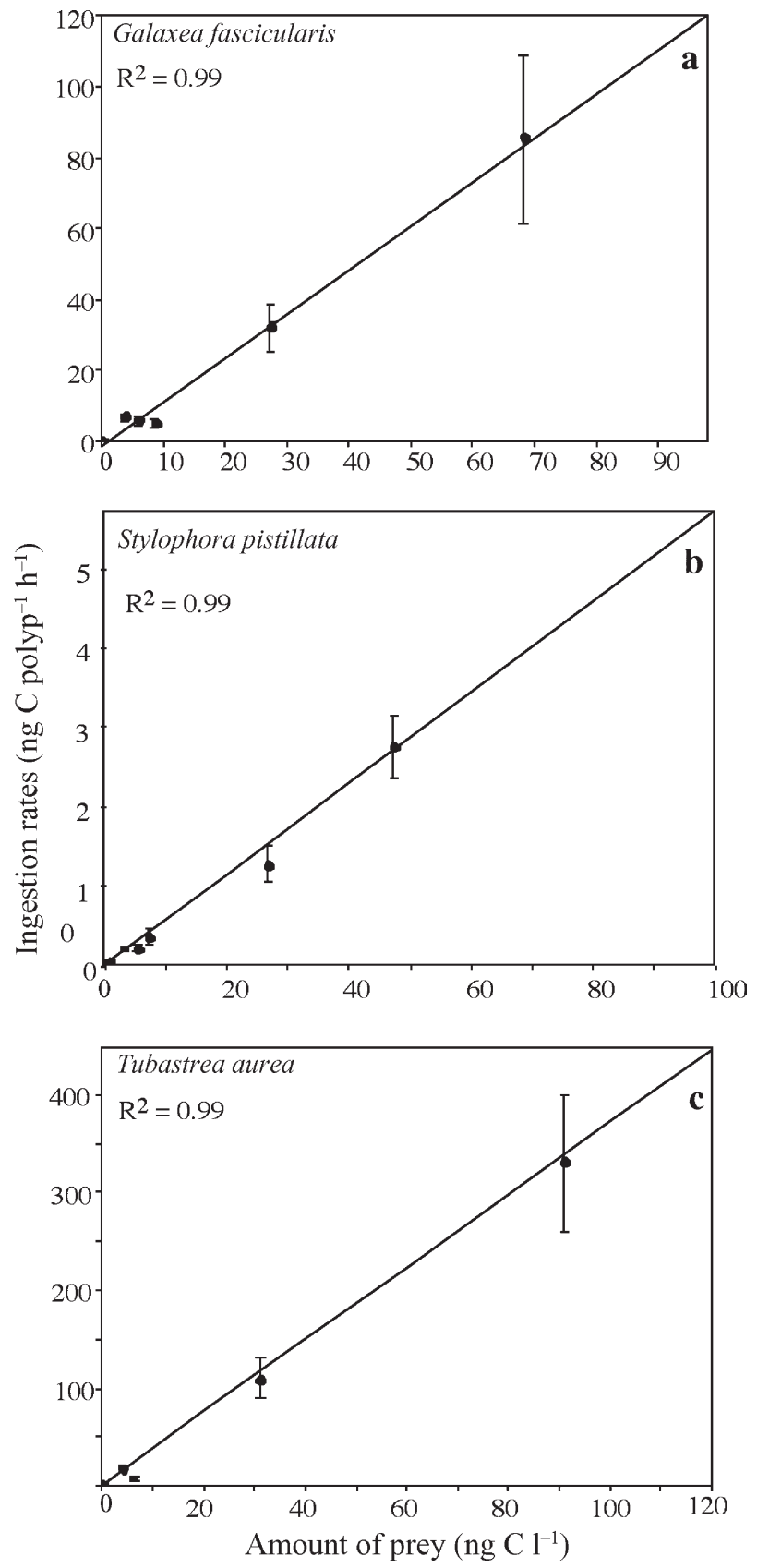

Fig. 4. Ingestion rates versus the amount of prey in the seawater for (a) Galaxea fascicularis, (b) Stylophora pistillata and

(c) Tubastrea aurea (mean $\pm \mathrm{SD}, \mathrm{n}=15$ for each species) observed in the control chambers. Many studies have demonstrated that corals excrete DOC and dissolved organic nitrogen together with mucus (Crossland 1987, Bythell 1988, Yamamuro \& Kayanne 1997, Ferrier-Pagès et al. 1998). Crossland (1987) was one of the first to investigate release rates of mucus and DOC-lipid in Acropora variabilis. He found that DOClipid represented $75 \%$ of the total excreted organic carbon and 10 to $21 \%$ of the net photosynthetically fixed carbon. Ferrier-Pagès et al. (1998) showed that DOC release by the coral $G$. fascicularis accounted for ca. 11 to $14 \%$ of the daily photosynthetically fixed carbon. Wild et al. (2004) finally showed that the mucus released by corals trapped particles and made them available to the heterotrophic reef community. Conversely to G. fascicularis and T. aurea, DOC concentrations decreased in all tanks containing Stylophora pistillata (after having taken into account DOC changes in the control chambers), suggesting an active uptake by this coral. Such uptake has already been demonstrated in a few previous studies on other coral species (Ferrier 1991, Al-Moghrabi et al. 1993, Hoegh-Guldberg \& Williamson 1999). However, in these above studies, DOC was mainly in the form of amino acids, which are known to be labile and easy to take up. Whether corals release or take up DOC, and in which form, however, remains to be further investigated. In gorgonians, in situ studies never showed significant uptake of DOC (Ribes et al. 1998, 1999, Coma \& Ribes 2003).

This study represents a first estimate of the contribution of pico- and nanoplankton to the nutrient budget of corals. Our results indicate that at least nanoplankton may be a major food source for scleractinian corals, which is abundant and constantly available in the waters surrounding every coral colony. Corals are, therefore, able to feed on a wide and heterogeneous diet.

Acknowledgements. Support for this work was provided by the Centre Scientifique de Monaco. We are specially grateful to J. P. Gattuso, B. Delesalle as well as to 4 anonymous reviewers for critical reading and valuable comments on this manuscript. DOC analyses were performed at the Marine Station of Villefranche-sur-Mer, with the valuable help of E. Rochelle-Newall.

Table 5. Change in DOC concentrations during the incubation (mean $\pm \mathrm{SD})(\mathrm{n}=15) . T_{0}$ and $T_{6}$ correspond to the beginning and the end of the incubation time

\begin{tabular}{|c|c|c|c|c|}
\hline \multirow{2}{*}{ Coral species } & \multicolumn{2}{|c|}{$\mathrm{DOC}\left(\mu \mathrm{mol} \mathrm{l} \mathrm{l}^{-1}\right)$} & \multirow{2}{*}{\multicolumn{2}{|c|}{ 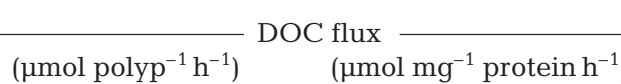 }} \\
\hline & $T_{0}$ & $T_{6}$ & & \\
\hline Tubastrea aurea & $97.89 \pm 09.45$ & $124.63 \pm 10.86$ & $+0.23 \pm 0.17$ & $+0.02 \pm 0.01$ \\
\hline Galaxea. fascicularis & $79.62 \pm 11.28$ & $105.53 \pm 07.82$ & $+0.10 \pm 0.10$ & $+0.19 \pm 0.17$ \\
\hline Stylophora pistillata & $101.69 \pm 13.53$ & $93.59 \pm 04.67$ & $-0.25 \pm 0.22$ & $-0.01 \pm 0.01$ \\
\hline
\end{tabular}




\section{LITERATURE CITED}

Al-Moghrabi S, Allemand D, Jaubert J (1993) Valine uptake by the scleractinian coral Galaxea fascicularis characterization and effect of light and nutritional status. J Comp Physiol B 163:355-362

Al-Moghrabi S, Goiran C, Allemand D, Speziale N, Jaubert J (1996) Inorganic carbon uptake for photosynthesic coral/ dinoflagellates association. II. Mechanisms for bicarbonate uptake. J Exp Mar Biol Ecol 199:227-248

Anthony KRN (1997) Prey capture by the sea anemone Metridium senile (L.): effects of body size, flow regime, and upstream neighbors. Biol Bull 192:73-86

Anthony KRN (1999) Coral suspension feeding on fine particulate matter. J Exp Mar Biol Ecol 23:85-106

Anthony KRN, Fabricius KE (2000) Shifting roles of heterotrophy and autotrophy in coral energetics under varying turbidity. J Exp Mar Biol Ecol 252:221-253

Atkinson MJ, Bilger RW (1992) Effects of water flow velocity on phosphate uptake in coral reef-flat communities. Limnol Oceanogr 37(2):273-279

Ayukai T (1995) Retention of phytoplankton and planktonic microbes on coral reefs within the Great Barrier Reef, Australia. Coral Reefs 14:141-147

Azam F, Fenchel T, Field JG, Gray JS, Meyer-Reil LA, Thingstad F (1983) The ecological role of water column microbes in the sea. Mar Ecol Prog Ser 10:257-263

Bak RPM, Joenje M, deJong I, Lambrechts DYM, Newland G (1998) Bacterial suspension feeding by coral reef benthic organisms. Mar Ecol Prog Ser 175:285-288

Bratbak G (1987) Carbon flow in an experimental microbial ecosystem. Mar Ecol Prog Ser 36(3):267-276

Bythell JC (1988) A total nitrogen and carbon budget for the elkhorn coral Acropora palmata (Lamarck). Proc 6th Int Coral Reef Symp Aust 2:535-540

Caron DA, Dam HG, Kremer P, Lessard EJ and 6 others (1995) The contribution of microorganisms to particulate carbon and nitrogen in surface waters of the Sargasso Sea near Bermuda. Deep-Sea Res I 42(6):943-972

Clayton WS, Lasker HR (1982) Effects of light and dark treatments on feeding by the reef coral Pocillopora damicornis. J Exp Mar Biol Ecol 63:269-279

Coma R, Ribes M (2003) Seasonal energetic constraints in Mediterranean benthic suspension feeders: effects of different levels of ecological organization. Oikos 101: 205-215

Coma R, Ribes M, Orejas C, Gili JM (1999) Prey capture by a benthic coral reef hydrozoan. Coral Reefs 18:141-145

Cook CB, Muller-Parker G, Orlandini CD (1994) Ammonium enhancement of dark carbon fixation and nitrogen limitation in zooxanthellae symbiotic with the reef corals Madracis mirabilis and Montastrea annularis. Mar Biol 118:157-165

Crossland CJ (1987) In situ release of mucus and DOC-lipid from the corals Acropora variabilis and Stylophora pistillata in different light regimes. Coral Reefs 6:35-42

DiSalvo LH (1971) Regenerative functions and microbial ecology of coral reefs: labelled bacteria in a coral reef microcosm. J Exp Mar Biol Ecol 7:123-136

Ducklow HW (1990) The biomass, production and fate of bacteria in coral reefs. In: Dubinsky Z (ed) Coral reefs, ecosystem of the world, Vol 25. Elsevier, Amsterdam, p 265-289

Edler L (1979) Recommendations for marine biological studies in the Baltic sea: phytoplankton and chlorophyll. Balt Mar Biol 5:5-38

Edmunds P, Gates R (2002) Normalizing physiological data for scleractinian corals. Coral Reefs 21(2):193-197
Fabricius K, Benayahu Y, Genin A (1995) Herbivory in asymbiotic soft corals. Science 268:90-93

Fabricius K, Yahel G, Genin A (1998) In situ depletion by an azooxanthellate soft coral. Limnol Oceanogr 43(2):354-356

Falkowski PG, Dubinsky Z, Muscatine L, Porter JW (1984) Light and bioenergetics of a symbiotic coral. BioScience 11:705-709

Farrant PA, Borowitzka MA, Hinde R, King RJ (1987) Nutrition of the temperate australian soft coral Capnella gaboensis. Mar Biol 95:575-581

Ferrier MD (1991) Net uptake of dissolved free amino acids by 4 scleractinian corals. Coral Reefs 10:183-187

Ferrier-Pagès C, Gattuso JP (1998) Biomass, production and grazing rates of pico and nanoplankton in coral reef waters (Miyako Island, Japan). Microb Ecol 35:48-57

Ferrier-Pagès C, Gattuso JP, Cawet G, Jaubert J, Allemand D (1998) Release of dissolved organic carbon and nitrogen by the zooxanthellate coral Galaxea fascicularis. Mar Ecol Prog Ser 172:265-274

Ferrier-Pagès C, Witting J, Tambutté E, Sebens KP (2003) Effects of natural zooplankton feeding on the tissue and skeletal growth of the scleractinian coral Stylophora pistillata. Coral Reefs 22:229-240

Frost BW (1972) Effects of size and concentration of food particles on the feeding behaviour of the marine planktonic copepod Calanus pacificus. Limnol Oceanogr 17:805-815

Gattuso JP (1987) Ecomorphologie, métabolisme, croissance et calcification du scléractiniaire à zooxanthelles Stylophora pistillata (Golfe d'Aqaba, Mer Rouge). Influence de l'éclairement. $\mathrm{PhD}$ thesis, Aix-Marseille

Grottoli AG (2000) Stable carbon isotopes $\left(\delta^{13} \mathrm{C}\right)$ in coral skeletons. Oceanography 13:93-97

Grottoli AG, Wellington GM (1999) Effect of light and zooplankton on skeleton $\delta^{13} \mathrm{C}$ values in the eastern pacific corals Pavona clavus and Pavona gigantea. Coral Reefs 18: $29-41$

Grover R, Maguer JF, Allemand D, Ferrier-Pagès C (2003) Nitrate uptake in the scleractinian coral Stylophora pistillata. Limnol Oceanogr 48(6):2266-2274

Grover R, Maguer JF, Reynaud-Vaganay S, Ferrier-Pagès C (2002) Uptake of ammonium by the scleractinian coral Stylophora pistillata: effect of feeding, light and ammonium concentrations. Limnol Oceanogr 47:782-790

Gundersen K, Heldal M, Nordland S, Purdie DA, Knap AH (2002) Elemental C, N, and P cell content of individual bacteria collected at the Bermuda Atlantic Time-series Study (BATS) site. Limnol Oceanogr 47:1525-1530

Gundersen K, Orcutt KM, Purdie DA, Michaels AF, Knap AH (2001) Particulate organic carbon mass distribution at the Bermuda Atlantic Time-series Study (BATS) site. DeepSea Res Part II 48(8-9):1697-1718

Heldal M, Scanlan DJ, Norland S, Thingstad F, Mann NH (2003) Elemental composition of single cells of various strains of marine Prochlorococcus and Synechococcus using X-ray microanalysis. Limnol Oceanogr 48(5):1732-1743

Helmuth B, Sebens K (1993) The influence of colony morphology and orientation to flow on particle capture by the scleractinian coral Agaricia agaricites (Linnaeus). J Exp Mar Biol Ecol 165:251-278

Herndl GJ, Velimirov B (1985) Bacteria in the coelenteron of Anthozoa: control of coelenteric bacterial density by the coelenteric fluid. J Exp Mar Biol Ecol 93:115-130

Hoegh-Guldberg O, Williamson J (1999) Availability of two forms of dissolved nitrogen to the coral Pocillopora damicornis and its symbiotic zooxanthellae. Mar Biol 133:561-570

Houlbrèque F, Tambutté E, Ferrier-Pagès C (2003) Effect of zooplankton availability on the rates of photosynthesis, 
and tissue and skeletal growth in the scleractinian coral Stylophora pistillata. J Exp Mar Biol Ecol 296:145-166

Jochem F (1988) On the distribution and importance of picocyanobacteria in a boreal inshore area (Kiel Bight, Western Baltic). J Plankton Res 10(5):1009-1022

Johannes RE, Tepley L (1974) Examination of feeding on the reef coral Porites lobata in situ using time lapse photography. Proc 2nd Int Coral Reef Symp Brisbane 1:127-131

Johnson AS, Sebens KP (1993) Consequences of a flattened morphology: effects of flow on feeding rates of the scleractinian coral Meandrina meandrites. Mar Ecol Prog Ser 99:99-114

Kim K, Lasker HR (1997) Flow-mediated resource competition in the suspension feeding gorgonian Plexaura homomalla (Esper). J Exp Mar Biol Ecol 215:49-64

LaBarbera M (1984) Feeding currents and particle capture mechanisms in suspension feeding animals. Mar Zool 24: 71-84

Lasker HR (1981) Phenotypic variation in the coral Montastrea cavernosa and its effects on colony energetics. Biol Bull 160:292-302

Lasker HR, Gottfried MD, Coffroth MA (1983) Effects of depth on the feeding capabilities of two octocorals. Mar Biol 73: 73-78

Levy O, Mizrahi L, Chadwick-Furman NE, Achituv Y (2001) Factors controlling the expansion behavior of Favia favus (Cnidaria: Scleractinia). Effects of light, flow and planktonic prey. Biol Bull 200:118-126

Lewis JB (1992) Heterotrophy in corals: zooplankton predation by the hydrocoral Millepora complanata. Mar Ecol Prog Ser 90:251-256

Moriarty DWJ, Pollard PC, Alongi DM, Willkinson CR, Gray JS (1985) Bacterial productivity and trophic relationships with consumers on a coral reef. Proc 5th Int Coral Reef Symp 3:457-462

Muscatine L (1973) Nutrition of corals. In: Jones OA, Endean R (eds) Biology and geology of coral reefs. II. Biology 1. Academic Press, New York, p 72-112

Muscatine L, Kaplan IR (1994) Resource partitioning by reef corals as determined from stable isotope composition II. $\delta^{15} \mathrm{~N}$ of zooxanthellae and animal tissue vs depth. Pac Sci 48(3):304-312

Muscatine L, Porter JW (1977) Reef corals: mutualistic symbioses adapted to nutrient-poor environments. BioScience $27(7): 454-460$

Piniak GA (2002) Effects of symbiotic status, flow speed, and prey type on prey capture by the facultatively symbiotic temperate coral Oculina arbuscula. Mar Biol 141:449-455

Platt T, Rao DVS, Irwin B (1983) Photosynthesis of picoplankton in the oligotrophic ocean. Nature 301(5902):702-704

Pomeroy LR, Pilson MEQ, Wiebe WJ (1974) Tracer studies of the exchange between reef water and organisms on the windward reef of Eritvetok atoll. Proc 2nd Int Coral Reef Symp Brisbane 1:87-97

Porter JW (1974) Zooplankton feeding by the Caribbean reefbuilding coral Montastrea annularis. Proc 2nd Int Coral Reef Symp Brisbane 1:111-125

Porter KG, Feig YS (1980) The use of DAPI for identifying and counting aquatic microflora. Limnol Oceanogr 25:943-948

Reiswig HM (1971) Particle feeding in natural populations of three marine demosponges. Biol Bull 141:568-591

Ribes M, Coma R, Gili JM (1998) Heterotrophic feeding by gorgonian corals with symbiotic zooxanthellae. Limnol Oceanogr 43(6):1170-1179

Ribes M, Coma R, Gili JM (1999) Heterogeneous feeding in benthic suspension feeders: the natural diet and grazing rates of the temperate gorgonian Paramuricea clavata
(Cnidaria: Octocorallia) over a year cycle. Mar Ecol Prog Ser 183:125-137

Ribes M, Coma R, Atkinson MJ, Kinzie RA III (2003) Particle removal by coral reef communities: picoplankton is a major source of nitrogen. Mar Ecol Prog Ser 257:13-23

Risk MJ, Sammarco PW, Schwarcz HP (1994) Cross continental shelf trends in $\delta^{13} \mathrm{C}$ in coral of the Great Barrier Reef. Mar Ecol Prog Ser 106:121-130

Sebens KP (1987) Coelenterata. In: Vernberg FJ, Pandian TJ (eds) Animal energetics. Academic Press, New York, p 55-120

Sebens KP, Johnson AS (1991) Effects of water movement on prey capture and distribution of reef corals. Hydrobiologia 226:91-101

Sebens KP, Vandersall KS, Savina LA, Graham KR (1996) Zooplankton capture by two scleractinian corals Madracis mirabilis and Montastrea cavernosa in a field enclosure. Mar Biol 127:303-317

Sebens KP, Witting W, Helmuth B (1997) Effects of water flow and branch spacing on particle capture by the reef coral Madracis mirabilis (Duchassaing and Michelotti). J Exp Mar Biol Ecol 211:1-28

Sharp JH (1997) Marine dissolved organic carbon: are the older values correct? Mar Chem 56(3-4):265-277

Sheldon RW, Rassoulzadegan F (1987) A method for measuring plankton production by particle counting. Mar Microb Food Webs 2(1):29-44

Smith KL Jr, Kaufmann RS (1999) Long-term discrepancy between food supply and demand in the deep eastern North Pacific. Science 284(5417):1174-1177

Smith PK, Krohn RI, Hermanson GT, Mallia AK and 6 others (1985) Measurement of protein using bicinchroninic acid. Anal Biochem 150:76-85

Sorokin YI (1973) On the feeding of some scleractinian corals with bacteria and dissolved organic matter. Limnol Oceanogr 18(3):380-385

Sorokin YI (1991) Biomass, metabolic rates and feeding of some common reef zoantharians and octocorals. Aust J Mar Freshw Res 42:729-741

Stockner JG, Antia NJ (1986) Algal picoplankton from marine and freshwater ecosystems: a multidisciplinary perspective. Can J Fish Aquat Sci 43:2472-2503

Trager GC, Hwang JS, Strickler JR (1990) Barnacle suspension-feeding in variable flow. Mar Biol 105(1):117-127

Tremblay JE, Legendre L (1994) A model for the size-fractionated biomasses and production of marine phytoplankton. Limnol Oceanogr 39(8):2004-2014

Veron JEN (2000) Corals of the world, Vol 3. Australian Institute of Marine Sciences, Townsville

Veron JEN, Pichon M (1976) Scleractinia of Eastern Australia Part I: Families Thannasteriidae, Astrocoeniidae, Pocilloporidae. Aust Inst Mar Sci Monogr Ser 1:1-86

Vogel S, LaBarbera M (1978) Simple flow tanks for research and teaching. BioScience 28:638-643

Wild C, Huettel M, Klueter A, Kremb SG, Rasheed MYM, Jorgensen BB (2004) Coral mucus functions as an energy carrier and particle trap in the reef ecosystem. Nature 428:66-70

Witting JH (1999) Zooplankton capture and coral growth: the role of heterotrophy in Carribean reef corals. $\mathrm{PhD}$ thesis, Northeastern University, Boston, MA

Yahel G, Sharp JH, Marie D, Haese C, Genin A (2003) In situ feeding and element removal in the symbiont-bearing sponge Theonella swinhoei: bulk DOC is the major source for carbon. Limnol Oceanogr 48(1):141-149

Yamamuro M, Kayanne H (1997) Dissolved organic nitrogen flux from coral colonies and calcareous sandy sediment. Galaxea 13:197-205 